\title{
A Decision Support Platform based on Cross-Sorting Methods for the Selection of Modeling Methods
}

\author{
Case of the Hospital Supply Chain Performance Analysis
}

\author{
Manal Tamir ${ }^{1}$, Raddouane Chiheb ${ }^{3}$ \\ Advanced Digital Enterprise Modeling and Information \\ Retrieval Laboratory, Rabat IT Center \\ ENSIAS, Mohamed V University \\ Rabat, Morocco
}

\author{
Fatima Ouzayd ${ }^{2}$ \\ Smart Systems Laboratory, Rabat IT Center, \\ ENSIAS, Mohamed V University, \\ Rabat, Morocco
}

\begin{abstract}
The hospital supply chain performance is a concept that qualifies the good governance, the continuous improvement and the optimization of human and material resources of the hospital system. Thus, several performance analysis methods have been proposed for qualifying organizational flows and resources management. The main goal of the present study is to expose a literature review of the main graphical modeling and performance analysis techniques used in different research projects in the hospital field. The literature review will be analyzed and complemented by a classification study of the previous techniques. It is about a review in which will be proposed a computer platform based on Multi-Criteria Decision Analysis. This platform uses fuzzy pairwise comparisons and cross-sorting methods. Finally, the classification study is chosen in order to highlight the most adapted techniques to the different characteristics and components of the hospital system as part of the overall support decision process.
\end{abstract}

Keywords-Hospital supply chain; graphical modeling and performance analysis techniques; multi-criteria decision analysis; fuzzy pairwise comparisons; support decision process; computer platform; cross-sorting methods

\section{INTRODUCTION}

Currently, healthcare system challenges aren't limited to provide high-level service to patients at all costs, but it include optimization of hospitals expenses by decreasing costs and increasing productivity of resources.

In fact, for succeeding these challenges, the hospital decision makers must understand the complexity of the healthcare system at different levels. The authors of [1] have proposed: "they need to recognize the types of sub-systems that constitute the whole healthcare system, the operations within each sub-system, the main bottlenecks and their causes, which actions are efficient and which are not, and the impact of changes and actions on the overall performance system".

The major reflection of researchers in the healthcare field is the performance improvement of the hospital supply chain. Indeed, the authors of [2] explain that the improvement needs to be continuous by analyzing continually the performance in order to highlight aspects and action variables that influence directly the hospital system. For this purpose, several research works presented in the literature have treated the performance analysis concept in the hospital field and have used to this purpose different modeling methods. In fact, system performance analysis or improvement will be done by using modeling methods that allow describing the organization of the processes. The next step is about simulating it and comparing the different scenarios, or by analyzing and restructuring them.

In the hospital supply chain context, the development of modeling methods is done by considering the problems from which the system suffers and which hinder its development and performance.

Two types of performance analysis procedures exist [2]:

- Priori approach: To establish firstly a model, analyze and apply it to achieve its performance. The result will be compared with the predefined objectives and different changes of the model action variables will be proposed until stabilizing the model.

- Posteriori approach: To measure performances of an existing real system. Then, compare these measures with the predefined objectives and propose actions in order to improve the system.

In our present case, we will study the posteriori performance evaluation approach by considering the hospital system as an existing real system that the major studies focus on its identification and improvement.

However, the question is: Which of the several modeling methods to choose for describing effectively the hospital supply chain? Any system must to be modeled with respect to the strategy and the nature of the company's business. Therefore, our main work is based on the research in the literature of the several modeling methods, nature of stakeholders in their uses and recommendations of experts concerning their performances and limitations.

For this reason, we propose in this paper, the multi-Criteria decision analysis based on fuzzy pairwise comparisons to succeed the making decision process dedicated for choosing the best modeling methods.

The remainder of this paper is structured as follows: In section 2, we give an abstract about the different definitions given in the literature to hospital supply chain and its global 
structure. Then, we propose in section 3, a benchmark of the different modeling methods used in the hospital supply chain.

In section 4, we develop the classification study by identifying our methodology of research, determining criteria and applying the calculation algorithm.

\section{Literature REVIEW : MODELING METHODS IN HOSPITAL SUPPLY CHAIN}

\section{A. Hospital Supply Chain}

The hospital system has been defined in the literature by all the flows (physical flow, informational flow and financial flow) which ensure the proper functioning of its institutions. The authors of [3] characterized the hospital system by an open system which is in interaction with external entities (logistic or medical service delivery entities). An analogy between hospital system and industrial system was mentioned in [4] and [5] by considering the process of production and in [3] by considering the orientation of flows and nature of stakeholders.

Thus, the performance in hospital supply chain has become instead of the qualification of the medical treatments a qualification of the sector organization and the quality of the care service [6]. Otherwise, the good management of material flow and patient flow are the keys for improving the hospital supply chain performance.

Several definitions of the hospital supply chain have been developed throughout the years. In fact, a set of dimensions have been developed to cover the integral definition of this supply chain (managerial and technical aspects [7]).

The notion of support logistics has been mentioned in [8]; it concerns supply, handling, maintenance and installation activities. The authors of [9] have based the hospital supply chain activities on three main activities: supply, production and distribution. Thus, according to [10] the hospital supply chain consists of the information, service, patients and physical flows management from the suppliers to the patients.

In [7], the author proposes the following definition: "Hospital supply chain is the set of design activities, planning, procurement management, manufacturing (goods and services), delivery and return management, from the provider to the beneficiary (patients), taking into account all the trajectories of the patients in the hospital without which there is no product flows (pharmaceutical). These activities are driven by the information flow between the various partners in the supply chain and lead to financial flows. The aim is to provide optimal service for the quality and safety of patient care".

After scanning several definitions that were given by the literature, the next section will be dedicated to discover more deeply the structure and the different stakeholders of the hospital supply chain.

\section{B. Structure of the Hospital Supply Chain}

In this section, we will try to detail the global structure of the hospital supply chain, the different internal flows and those that are in interaction with external stakeholders.

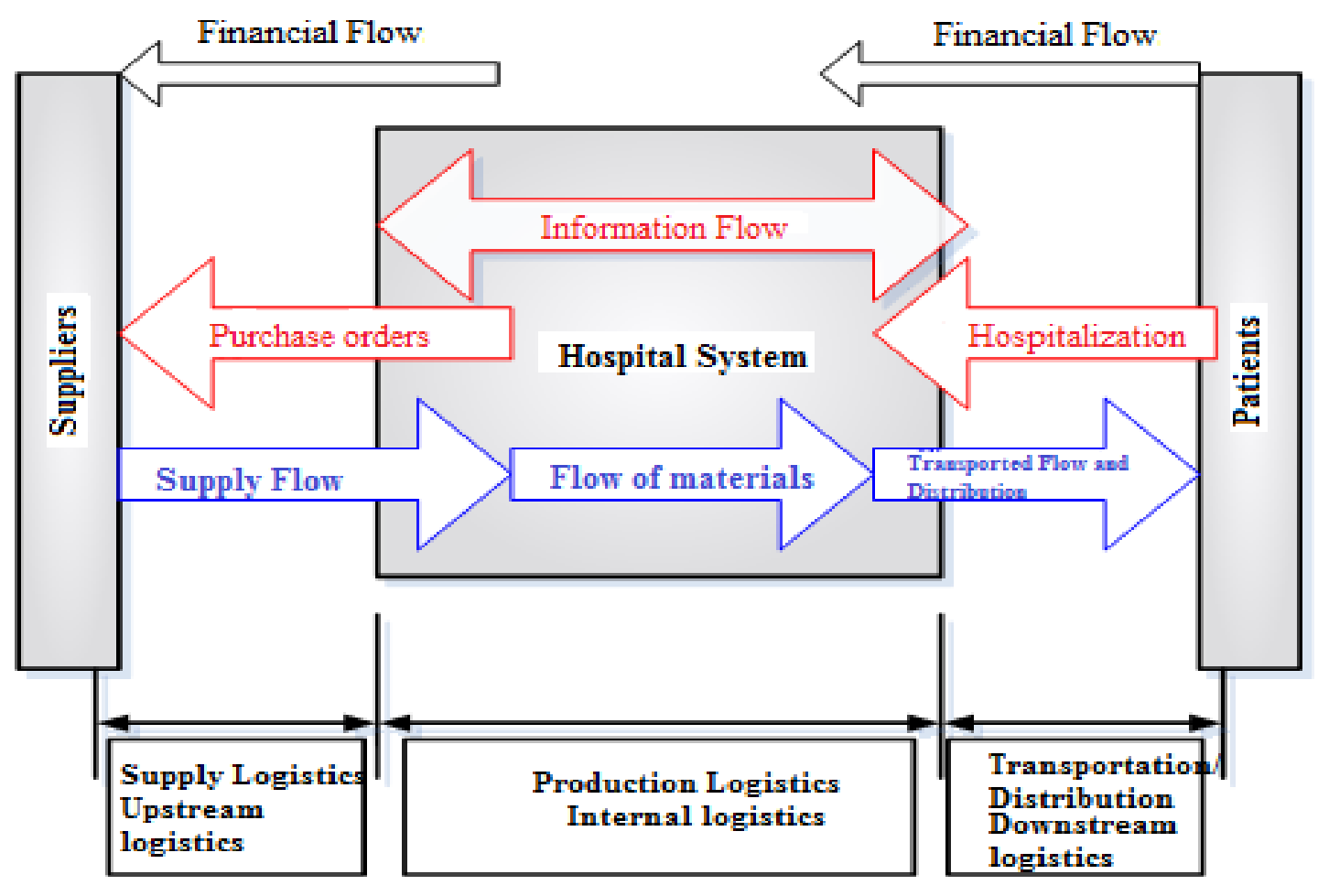

Hospital Supply Chain

Fig. 1. The Structure of the Global Hospital Supply Chain According to [2]. 
According to [11], health institutions have five main activities and several types of inputs (patients and primary entrants) and outputs (intermediate and final outputs) are involved for the implementation of these activities. Otherwise, [12] was based to establish its proposal for the hospital supply chain structure on the following five factors which are related to the product life cycle: design, production, exploitation, distribution, destruction or recycling.

Moreover, [7] gives a proposal for the structure which focuses on the pharmaceutical component of the hospital system. Its proposal includes three levels. Firstly, an upstream level where the main actors are the suppliers or manufacturers of the pharmacy; The suppliers ensure the supply of pharmaceutical products to the pharmacy. Secondly, a first downstream level which characterizes the relationship between the pharmacy and the other services. The main activity of the pharmacy is to provide the pharmaceutical products received from the suppliers after or without transformation to the different hospital services. Finally, a second downstream level that concludes stocks management, returns management and the supply of pharmaceutical products to patients.

From the previous definitions, it is proposed a structure that implements the different levels and components of the hospital supply [2] (see Figure1):

\section{Graphical Modeling Methods}

The literature has been enriched in recent years by several researches dealing with the problems of hospital system. In this section, we analyze the different cases treated in the literature that concern the hospital supply chain and in which researchers have proposed performance analysis methods especially the graphical modeling methods.

The modeling studies that are present in the literature concern the main production flow within the hospital, patient flows, administrative flows and resources which are related to primary services as well as operating theaters, emergency units, consultation centers, etc. According to [7], the difficulties of optimizing flows and stocks pushed the managers to find balances and to discover new ways in order to rationalize expenditures and seek refined solutions to these new problems.

The remainder of this work focuses on methods that are used in the modeling and simulation approach. It is about modeling and simulating the action data by evaluating the performance of the system in order to reach the objectives represented by an interesting number of performance indicators [13].

In fact, it can be referred to two different types of studies [14]: studies that concern the planning and optimization of care production units ([15]; [16]) and that of operations management which propose models and the theories dealing with the current problems that the patient circuit knows in the hospital ([17];[18]; [7]; [6]).

For example, the author of [19] have linked in his work the following objectives to the modeling approach:

- Improvement of the decision-making organization and reduction of the hospitalization duration [20]
- Reduction of the waiting time in emergency unit [21]

- Reduction of the time spent by the patient in the emergency units and improvement of its performances [22]

- Restructuration of medical personnel assignment problem [23]

- Minimization of the pharmaceutical supply chain expenditures.

In each case study, the literature includes a framework rich in modeling methods and their attributions.

The modeling and simulation approach has used by the authors [6] to minimize the cycle time of the patient journey in emergency department, to improve the medicine drugs circuit in Moroccan hospital system [1] and to optimize the blood transfusion process in Blood Transfusion Regional Center of Casablanca-Morocco [23].

The authors of [6] used for the modeling part the IDEF3x method and for the simulation part the queue networks. The queuing theory was used by [22] in order to insure the optimal service rate by determining the adequate combinations of human and materiel resources to be attributed to each inpatient unit room. Researchers are also developed and adapted industrial platforms in order to exploit their strengths in producing outstanding results. For example, the industrial planning software (PREACTOR) was used by the author [18] for managing in real time the patient's trajectory in the hydrotherapy and the radiotherapy centers.

In the table below (table I), we indicate works applying modeling methods in the hospital supply chain.

TABLE I. GRAPHICAL MOdELING Methods APPLyed IN HoSPITAL SUPPLY CHAIN

\begin{tabular}{|l|l|l|l|}
\hline Authors & $\begin{array}{l}\text { Modeling } \\
\text { Method }\end{array}$ & Hospital Field & Flow Type \\
\hline$[24]$ & SADT & $\begin{array}{l}\text { Blood } \\
\text { transfusion }\end{array}$ & Informational flow \\
\hline$[25]$ & $\begin{array}{l}\text { UML, SADT } \\
\text { Petri Networks }\end{array}$ & $\begin{array}{l}\text { Hospital } \\
\text { Processes }\end{array}$ & $\begin{array}{l}\text { Patient flow, } \\
\text { informational flow }\end{array}$ \\
\hline$[26]$ & SADT & $\begin{array}{l}\text { Emergency } \\
\text { department }\end{array}$ & Patient flow \\
\hline$[6]$ & SADT & $\begin{array}{l}\text { Emergency } \\
\text { department }\end{array}$ & Patient flow \\
\hline$[27]$ & UML & $\begin{array}{l}\text { Hospital } \\
\text { processes }\end{array}$ & Patient flow \\
\hline$[28]$ & $\begin{array}{l}\text { UML, SADT } \\
\text { Petri Networks }\end{array}$ & $\begin{array}{l}\text { Production and } \\
\text { Distribution } \\
\text { supply chain }\end{array}$ & Materials flow \\
\hline$[29]$ & UML, Petri Net & $\begin{array}{l}\text { Hospital supply } \\
\text { chain }\end{array}$ & Drugs flow \\
\hline$[30]$ & ARIS & $\begin{array}{l}\text { Hospital Supply } \\
\text { Chain }\end{array}$ & Supply chain flows \\
\hline$[31]$ & BPMN & $\begin{array}{l}\text { Hospital } \\
\text { Materials }\end{array}$ & $\begin{array}{l}\text { Patient and materials } \\
\text { flows }\end{array}$ \\
\hline$[32]$ & BPMN, SCOR & $\begin{array}{l}\text { Drugs supply } \\
\text { chain }\end{array}$ & Drugs flow \\
\hline$[33]$ & BPM & $\begin{array}{l}\text { Hospital Supply } \\
\text { Chain }\end{array}$ & $\begin{array}{l}\text { Pharmaceutical } \\
\text { Products flow }\end{array}$ \\
\hline
\end{tabular}


In a similar study, [34] has attempted to analyze a set of modeling methods using the criteria proposed by CEN [35] to develop a system of performance indicators. In this context, a classification platform that will allow choosing the appropriate modeling method is proposed in the next section.

\section{THE DECISION SUPPORT PLATFORM FOR THE SELECTION OF MODELING METHODS IN THE HospitAL SUPPLY CHAIN}

\section{A. Research Methodology}

The global methodology adopted in this work for analyzing the literature review and developing the decision support platform is summarized on the following steps:

Step 1: To look for the modeling methods used in the hospital system literature. It is about the web-based search in electronic databases. The electronic databases chosen are as follows:

Level 1

Objective
Level 2

Criteria
- Thomason Reuters;

- ScienceDirect;

- DPLB;

- Springer;

- IEEE;

- IJACSA,

- Google scholar,

In this step, the following key words were adopted: hospital supply chain; performance analysis techniques; modeling; simulation.

Step 2: To sort the works obtained in the previous step by remaining in the study framework; refine the obtained database and eliminate any work that does not align with the main objective.

Level 3

High-level Criteria
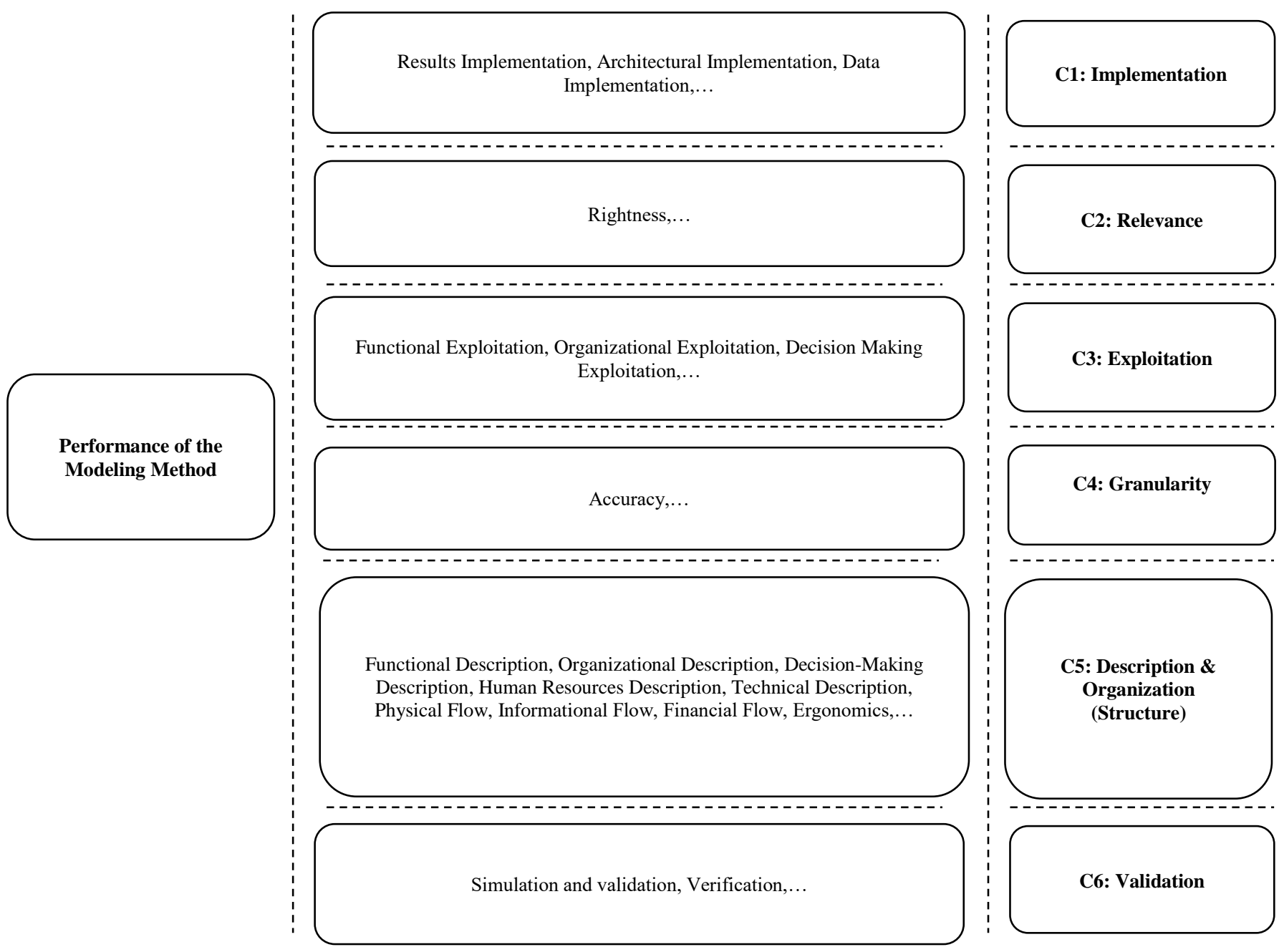

Fig. 2. Criteria of the Modeling Methods Performance. 
Step 3: To develop a platform based on the cross sorting methods and fuzzy pairwise comparisons for classifying modeling methods that are used in the literature; this classification framework uses the following criteria: Functional Description, Organizational Description, Decision-Making Description, Human Resources Description, Technical Description, Physical Flow, Information Flow, Financial Flow, Ergonomics, Rightness, Functional Exploitation, Organizational Exploitation, Decision Making Exploitation, Accuracy, Results Implementation, Architectural Implementation, Data Implementation, Simulation and validation, verification.

Step 4: To choose experts and request from them to fill the comparison matrices (comparison matrices of criteria and comparison matrix of methods).

Step 5: To classify methods of the literature according to the platform based on the cross sorting methods.

\section{B. The Modeling Methods: Application of the Classification Study}

Our classification study aims to analyze the adaptability of the modeling methods, used in the process of performance analysis, to the various components of the hospital supply chain. To do this, we tried at first to gather the most used techniques in the literature concerning the hospital sector and to classify them according to six criteria as developed on the next section (see Figure 2) by using multi-criterion decision analysis based on fuzzy pairwise comparisons.

1) Criteria of Modeling Methods Performance: In this section, we present criteria that are adopted for the comparison between different modeling methods. At first, the principal criteria of the modeling methods performance will be detailed. Secondly, the criteria will be grouped on six principal axes: Implementation, Relevance, Exploitation, Granularity, Description \& Organization (Structure) and Validation (see Figure 2).

2) Calculation of Final Scores (Scores of Criteria and Scores of Modeling Methods)

\section{a) Fuzzy Logic: Definition}

The fuzzy logic is based on the use of fuzzy numbers which are defined by distribution of possibility. The membership function $\mu$ identify this distribution by associating digital elements with different degrees of the possibility that vary between 0 and 1 [36]. In fact, the membership functions exist in different forms: Triangular, trapezoidal or Gaussian form [37].

The use of the fuzzy logic is large in the literature. In the rest of this work, it is opted for the triangular function adopted by [38] in their extension of the principle of least-squares logarithmic regression for taking into account the inaccuracy. The triangular function is defined by the lower value $\left(c_{1}\right)$, the modal value $\left(\mathrm{c}_{\mathrm{m}}\right)$ and the upper value $\left(\mathrm{c}_{\mathrm{u}}\right)$ as shown in the figure below (Figure 3).

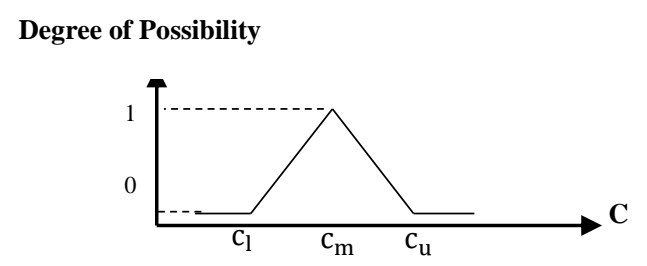

Fig. 3. Triangular Fuzzy Number.

\section{b) Description of the Calculation Algorithm}

To determinate the final scores of the studied modeling methods considering the six performance criteria of decision which are cited above, it is opted for the fuzzy multi criteria method proposed by [38] and modified by [39]. The choice of this method was not made arbitrarily but was based on the originality of his theory in terms of taking into account the inaccuracy in spite of the extensions which have been proposed later and which merely adopt other logics which also have their limitations or sometimes violate the assumptions of validity of the initial approach (for example the adoption of FWA algorithm in deterministic methods [36]).

In order to attack the allocation of triangular fuzzy pairwise comparisons, a decision committee of 3 members is defined A1, A2, A3.

The method will be applied in three main phases: Firstly, fuzzy weights $\widetilde{\alpha}_{i}=\left(\alpha_{i l}, \alpha_{i m}, \alpha_{i u}\right) i=1, \ldots, m$ will be assigned to the performance criteria of decision based on fuzzy pairwise comparisons $\widetilde{r_{1 j k}}=\left(r_{i j k l}, r_{i j k m}, r_{i j k u}\right)(i, j=1, \ldots, m)$ given by committee members $\mathrm{k}=1,2,3$. Secondly, fuzzy weights $\widetilde{\beta_{1 j}}=\left(\beta_{i j l}, \beta_{i j m}, \beta_{i j u}\right)(i, j=1, \ldots, n)$ will be estimated for methods under each of the criteria separately. Lastly, the final scores of methods $\omega_{j} \mathrm{j}=1, \ldots, \mathrm{n}$ are calculated by the aggregation of the calculated weights according to the formula below:

$\omega_{j}=\sum_{i=1}^{m} \alpha_{i} \beta_{i j} \quad j=1, \ldots \ldots, n$

In fact, the weights will be estimated by minimizing a logarithmic regression function as shown in the formula (2) below and the fuzzy weights are deduced by the following developed formulas $(3,4,5,6,7,8)$ :

$$
\begin{aligned}
& \ln \left(\alpha_{\mathrm{i}}\right) \sum_{\mathrm{j} \neq \mathrm{i}}^{\mathrm{m}} \delta_{\mathrm{ij}}-\sum_{\mathrm{j} \neq \mathrm{i}}^{\mathrm{m}} \delta_{\mathrm{ij}} \ln \left(\alpha_{\mathrm{j}}\right)= \\
& \sum_{\mathrm{j} \neq \mathrm{i}}^{\mathrm{m}} \sum_{\mathrm{k} \in \mathrm{D}_{\mathrm{ij}}} \ln \left(\mathrm{r}_{\mathrm{ijk}}\right) \quad \mathrm{i}=1, \ldots \ldots, \mathrm{m} \\
& \ln \left(\alpha_{\mathrm{il}}\right) \sum_{\mathrm{j} \neq \mathrm{i}}^{\mathrm{m}} \delta_{\mathrm{ij}}-\sum_{\mathrm{j} \neq \mathrm{i}}^{\mathrm{m}} \delta_{\mathrm{ij}} \ln \left(\alpha_{\mathrm{ju}}\right)= \\
& \sum_{\mathrm{j} \neq \mathrm{i}}^{\mathrm{m}} \sum_{\mathrm{k} \in \mathrm{D}_{\mathrm{ij}}} \ln \left(\mathrm{r}_{\mathrm{ijkl}}\right) \quad \mathrm{i}=1, \ldots \ldots, \mathrm{m} \\
& \ln \left(\alpha_{\mathrm{im}}\right) \sum_{\mathrm{j} \neq \mathrm{i}}^{\mathrm{m}} \delta_{\mathrm{ij}}-\sum_{\mathrm{j} \neq \mathrm{i}}^{\mathrm{m}} \delta_{\mathrm{ij}} \ln \left(\alpha_{\mathrm{jm}}\right)= \\
& \sum_{\mathrm{j} \neq \mathrm{i}}^{\mathrm{m}} \sum_{\mathrm{k} \in \mathrm{D}_{\mathrm{ij}}}^{\mathrm{ln}} \ln \left(\mathrm{r}_{\mathrm{ijkm}}\right) \quad \mathrm{i}=1, \ldots \ldots, \mathrm{m} \\
& \ln \left(\alpha_{\mathrm{iu}}\right) \sum_{\mathrm{j} \neq \mathrm{i}}^{\mathrm{m}} \delta_{\mathrm{ij}}-\sum_{\mathrm{j} \neq \mathrm{i}}^{\mathrm{m}} \delta_{\mathrm{ij}} \ln \left(\alpha_{\mathrm{jl}}\right)= \\
& \sum_{\mathrm{j} \neq \mathrm{i}}^{\mathrm{m}} \sum_{\mathrm{k} \in \mathrm{D}_{\mathrm{ij}}}^{m} \ln \left(\mathrm{r}_{\mathrm{ijku}}\right) \\
& \widetilde{\alpha}_{\mathrm{i}}=\left(\mathrm{a} \exp \left(\mathrm{x}_{\mathrm{il}}\right), \mathrm{b} \exp \left(\mathrm{x}_{\mathrm{im}}\right), \mathrm{a} \exp \left(\mathrm{x}_{\mathrm{iu}}\right)\right) \mathrm{i}=1, \ldots, \mathrm{m}, \\
& \mathrm{x}_{\mathrm{il}}=\ln \left(\alpha_{\mathrm{il}}\right) \quad \mathrm{x}_{\mathrm{im}}=\ln \left(\alpha_{\mathrm{im}}\right) \mathrm{x}_{\mathrm{iu}}=\ln \left(\alpha_{\mathrm{iu}}\right)
\end{aligned}
$$




$$
\begin{aligned}
& \mathrm{a}=\frac{1}{\left(\sum_{\mathrm{i}=1}^{\mathrm{m}} \exp \left(\mathrm{x}_{\mathrm{il}}\right) \sum_{\mathrm{i}=1}^{\mathrm{m}} \exp \left(\mathrm{x}_{\mathrm{iu}}\right)\right)^{\frac{1}{2}}}, \quad \mathrm{~b}=\frac{1}{\sum_{\mathrm{i}=1}^{\mathrm{m}} \exp \left(\mathrm{x}_{\mathrm{im}}\right)} \\
& \widetilde{\alpha}_{i}=\left(\begin{array}{c}
\alpha_{i l} \\
\alpha_{i m} \\
\alpha_{i u}
\end{array}\right)=\left[\begin{array}{c}
\frac{\exp \left(x_{i l}\right)}{\left(\sum_{j=1}^{m} \exp \left(x_{j l}\right) \sum_{j=1}^{m} \exp \left(x_{j u}\right)\right)^{\frac{1}{2}}} \\
\frac{\exp \left(x_{i m}\right)}{\sum_{j=1}^{m} \exp \left(x_{j m}\right)} \\
\frac{\exp \left(x_{i u}\right)}{\left(\sum_{j=1}^{m} \exp \left(x_{j l}\right) \sum_{j=1}^{m} \exp \left(x_{j u}\right)\right)^{\frac{1}{2}}}
\end{array}\right] i=1, \ldots, m
\end{aligned}
$$

c) Develpement of the Decision Support Platform: Application of the Calculation Algorithm

In the present case, it has be appealed to three expert professors and present them the table below (table1) that shows the five used linguistic values (Very High, High, Equal, Low and Very Low) and theirs estimated values on fuzzy numbers (see table II). The experts are required to fill separately the comparison matrix of the six criteria $(\mathrm{C} 1, \mathrm{C} 2, \mathrm{C} 3, \mathrm{C} 4, \mathrm{C} 5$ and C6) (see Figure 2).

TABLE II. FuZZy Numbers VALUes of Linguistic VAlues

\begin{tabular}{|l|l|l|}
\hline Linguistic Value & Designation & $\begin{array}{l}\text { Fuzzy Number } \\
\text { Value }\end{array}$ \\
\hline VH & Very High & $(7,9,10)$ \\
\hline H & High & $(6,7,9)$ \\
\hline E & Equal & $(3,5,7)$ \\
\hline L & Low & $(1,3,4)$ \\
\hline VL & Very Low & $(0,1,3)$ \\
\hline
\end{tabular}

In the order to make easier the calculation, we put $\alpha_{\mathrm{nl}}=1$ and $\alpha_{\mathrm{nm}}=1$ and the algorithm for resolving the three equations and calculating the normalized weights is developed on Matlab R2013a (see Figure 4).

The linguistic values and their correspondences on fuzzy numbers given by the three experts for comparing criteria are given in the table below (see table III).

From the results obtained by the developed platform, it can be noted that the weights of $\mathrm{C} 1, \mathrm{C} 2, \mathrm{C} 3$ and $\mathrm{C} 4$ are irrational fuzzy numbers that don't satisfy the condition "normalized lower value $\leq$ normalized mean value $\leq$ normalized upper value".

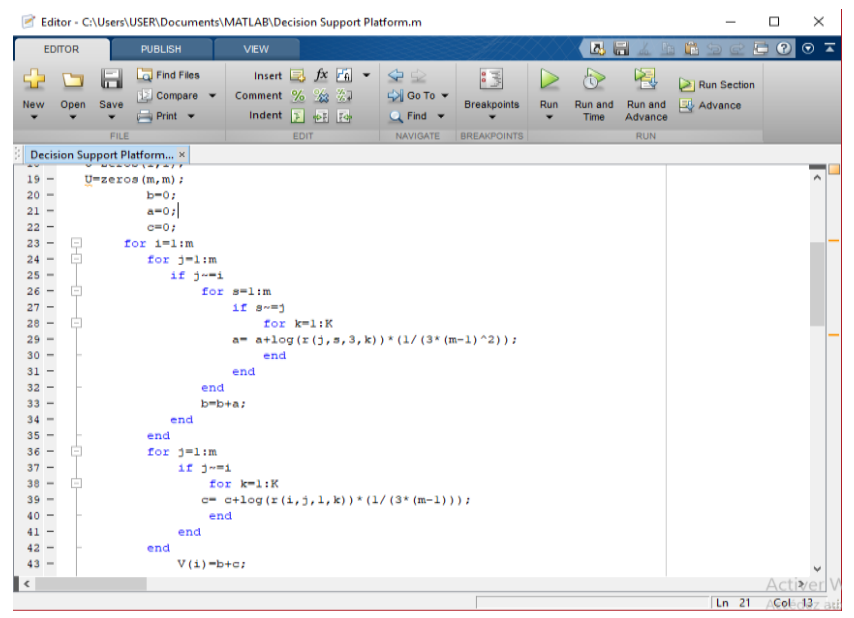

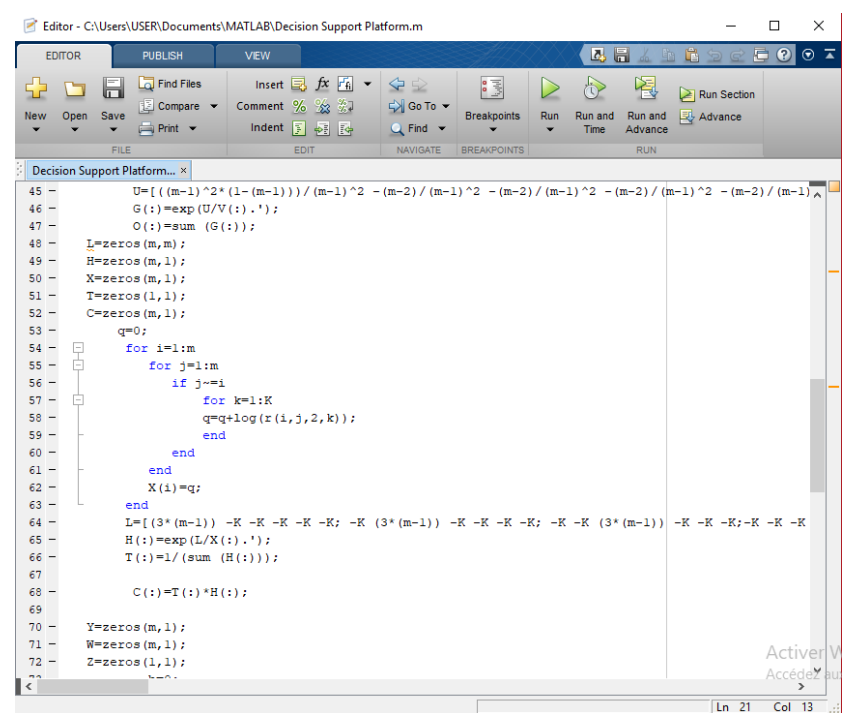

Fig. 4. The Implementation of the Decision Support Platform on Matlab R2013a.

The authors of [40] have already studied this point and criticize works of [38] and [39] in which normalized weights values that are derived from estimates based on ratio scales can generate an irrational ordering of fuzzy number's elements.

They tried to find the conditions on pairwise comparison values in order to get rational outcomes.

The condition is: $\quad \alpha_{\mathrm{il}} \leq \alpha_{\mathrm{iu}}$

That is equivalent to:

$\exp ((-0.0014 * \mathrm{~V}(1))+(0.009 *(\mathrm{~V}(2)+\mathrm{V}(3)+\mathrm{V}(4)+\mathrm{V}(5))))$;

$\mathrm{XY}=\exp ((0.0017 * \mathrm{Y}(1))+(0.0087 *(\mathrm{Y}(2)+\mathrm{Y}(3)+\mathrm{Y}(4)+\mathrm{Y}(5)))+(0$ $0086 * \mathrm{Y}(6)))$;

$\mathrm{YX}=\exp ((0.009 *(\mathrm{~V}(1)+\mathrm{V}(3)+\mathrm{V}(4)+\mathrm{V}(5)))-(0.2514 * \mathrm{~V}(2)))$;

$\mathrm{YY}=\exp ((0.0087 *(\mathrm{Y}(1)+\mathrm{Y}(3)+\mathrm{Y}(4)+\mathrm{Y}(5)))+(0.0086 * \mathrm{Y}(6))-$ $(0.2517 * \mathrm{Y}(2)))$;

$\mathrm{ZX}=\exp ((0.009 *(\mathrm{~V}(1)+\mathrm{V}(2)+\mathrm{V}(4)+\mathrm{V}(5)))-(0.2515 * \mathrm{~V}(3))) ;$

$\mathrm{ZY}=\exp ((0.0087 *(\mathrm{Y}(1)+\mathrm{Y}(2)+\mathrm{Y}(4)+\mathrm{Y}(5)))+(0.0086 * \mathrm{Y}(6))-$ $(0.2518 * \mathrm{Y}(3)))$;

$\mathrm{WX}=\exp ((0.009 *(\mathrm{~V}(1)+\mathrm{V}(2)+\mathrm{V}(3)+\mathrm{V}(5)))-(0.2514 * \mathrm{~V}(4)))$;

$\mathrm{WY}=\exp ((0.0087 *(\mathrm{Y}(1)+\mathrm{Y}(2)+\mathrm{Y}(3)+\mathrm{Y}(5)+\mathrm{Y}(6)))-$

$(0.2517 * \mathrm{Y}(4)))$;

$\mathrm{VX}=\exp ((0.009 *(\mathrm{~V}(1)+\mathrm{V}(2)+\mathrm{V}(3)+\mathrm{V}(4)))-(0.2514 * \mathrm{~V}(5)))$;

$\mathrm{VY}=\exp ((0.0087 *(\mathrm{Y}(1)+\mathrm{Y}(2)+\mathrm{Y}(3)+\mathrm{Y}(4)+\mathrm{Y}(6)))-$

$(0.2517 * \mathrm{Y}(5)))$;

$\mathrm{UX}=1$;

$\mathrm{UY}=\exp ((0.0087 *(\mathrm{Y}(1)+\mathrm{Y}(2)+\mathrm{Y}(3)+\mathrm{Y}(4)+\mathrm{Y}(5)))-$

$(0.2517 * \mathrm{Y}(6)))$;

The execution of the algorithm on Matlab R2013a gives the fuzzy weights shown on the Table IV. 
TABLE III. FuZZY PAIRwise COMPARISONS OF PERFormance CRITERIA

\begin{tabular}{|c|c|c|c|c|c|c|}
\hline & $\begin{array}{l}\text { C1 : } \\
\text { Implementation }\end{array}$ & $\begin{array}{l}\text { C2 : } \\
\text { Relevance }\end{array}$ & $\begin{array}{l}\text { C3 : } \\
\text { Exploitation }\end{array}$ & $\begin{array}{l}\text { C4 : } \\
\text { Granularity }\end{array}$ & $\begin{array}{l}\text { C5 : } \\
\text { Description \& } \\
\text { Organization } \\
\text { (Structure) }\end{array}$ & $\begin{array}{l}\text { C6 : } \\
\text { Validation }\end{array}$ \\
\hline $\begin{array}{l}\text { C1 : } \\
\text { Implementation }\end{array}$ & $(1,1,1)$ & $\begin{array}{l}\text { L: }(1,3,4) \\
\text { E: }(3,5,7) \\
\text { L: }(1,3,4)\end{array}$ & $\begin{array}{l}\text { H: }(6,7,9) \\
\text { E: }(3,5,7) \\
\text { L: }(1,3,4)\end{array}$ & $\begin{array}{l}\text { L: }(1,3,4) \\
\text { L: }(1,3,4) \\
\text { E: }(3,5,7)\end{array}$ & $\begin{array}{l}\text { E: }(3,5,7) \\
\text { H: }(6,7,9) \\
\text { L: }(1,3,4)\end{array}$ & $\begin{array}{l}\text { L: }(1,3,4) \\
\text { L: }(1,3,4) \\
\text { L: }(1,3,4)\end{array}$ \\
\hline $\begin{array}{l}\text { C2 : } \\
\text { Relevance }\end{array}$ & $\begin{array}{l}\frac{1}{L}:\left(\frac{1}{4}, \frac{1}{3}, 1\right) \\
\frac{1}{E}:\left(\frac{1}{7}, \frac{1}{5}, \frac{1}{3}\right) \\
\frac{1}{L}:\left(\frac{1}{4}, \frac{1}{3}, 1\right)\end{array}$ & $(1,1,1)$ & $\begin{array}{l}\text { H: }(6,7,9) \\
\text { E: }(3,5,7) \\
\text { E: }(3,5,7)\end{array}$ & $\begin{array}{l}\text { H: }(6,7,9) \\
\text { L: }(1,3,4) \\
\text { H: }(6,7,9)\end{array}$ & $\begin{array}{l}\text { H: }(6,7,9) \\
\text { VH: }(7,9,10) \\
\text { E: }(3,5,7)\end{array}$ & $\begin{array}{l}\text { L: }(1,3,4) \\
\text { L: }(1,3,4) \\
\text { E: }(3,5,7)\end{array}$ \\
\hline $\begin{array}{l}\text { C3 : } \\
\text { Exploitation }\end{array}$ & $\begin{array}{l}\frac{1}{H}:\left(\frac{1}{9}, \frac{1}{7}, \frac{1}{6}\right) \\
\frac{1}{E}:\left(\frac{1}{7}, \frac{1}{5}, \frac{1}{3}\right) \\
\frac{1}{L}:\left(\frac{1}{4}, \frac{1}{3}, 1\right)\end{array}$ & $\begin{array}{l}\frac{1}{H}:\left(\frac{1}{9}, \frac{1}{7}, \frac{1}{6}\right) \\
\frac{1}{E}:\left(\frac{1}{7}, \frac{1}{5}, \frac{1}{3}\right) \\
\frac{1}{E}:\left(\frac{1}{7}, \frac{1}{5}, \frac{1}{3}\right)\end{array}$ & $(1,1,1)$ & $\begin{array}{l}\text { L: }(1,3,4) \\
\text { L: }(1,3,4) \\
\text { E: }(3,5,7)\end{array}$ & $\begin{array}{l}\text { L: }(1,3,4) \\
\text { E: }(3,5,7) \\
\text { L: }(1,3,4)\end{array}$ & $\begin{array}{l}\text { L: }(1,3,4) \\
\text { L: }(1,3,4) \\
\text { L: }(1,3,4)\end{array}$ \\
\hline $\begin{array}{l}\text { C4 : } \\
\text { Granularity }\end{array}$ & $\begin{array}{l}\frac{1}{\mathrm{~L}}:\left(\frac{1}{4}, \frac{1}{3}, 1\right) \\
\frac{1}{\mathrm{~L}}:\left(\frac{1}{4}, \frac{1}{3}, 1\right) \\
\frac{1}{\mathrm{E}}:\left(\frac{1}{7}, \frac{1}{5}, \frac{1}{3}\right)\end{array}$ & $\begin{array}{l}\frac{1}{\mathrm{H}}:\left(\frac{1}{9}, \frac{1}{7}, \frac{1}{6}\right) \\
\frac{1}{\mathrm{~L}}:\left(\frac{1}{4}, \frac{1}{3}, 1\right) \\
\frac{1}{\mathrm{H}}:\left(\frac{1}{9}, \frac{1}{7}, \frac{1}{6}\right)\end{array}$ & $\begin{array}{l}\frac{1}{\mathrm{~L}}:\left(\frac{1}{4}, \frac{1}{3}, 1\right) \\
\frac{1}{\mathrm{~L}}:\left(\frac{1}{4}, \frac{1}{3}, 1\right) \\
\frac{1}{\mathrm{E}}:\left(\frac{1}{7}, \frac{1}{5}, \frac{1}{3}\right)\end{array}$ & $(1,1,1)$ & $\begin{array}{l}\text { H: }(6,7,9) \\
\text { VH: }(7,9,10) \\
\text { E: }(3,5,7)\end{array}$ & $\begin{array}{l}\text { L: }(1,3,4) \\
\text { L: }(1,3,4) \\
\text { E: }(3,5,7)\end{array}$ \\
\hline $\begin{array}{l}\text { C5 : } \\
\text { Description \& } \\
\text { Organization } \\
\text { (Structure) }\end{array}$ & $\begin{array}{l}\frac{1}{\mathrm{E}}:\left(\frac{1}{7}, \frac{1}{5}, \frac{1}{3}\right) \\
\frac{1}{\mathrm{H}}:\left(\frac{1}{9}, \frac{1}{7}, \frac{1}{6}\right) \\
\frac{1}{\mathrm{~L}}:\left(\frac{1}{4}, \frac{1}{3}, 1\right)\end{array}$ & $\begin{array}{c}\frac{1}{\mathrm{H}}:\left(\frac{1}{9}, \frac{1}{7}, \frac{1}{6}\right) \\
\frac{1}{\mathrm{VH}}:\left(\frac{1}{10}, \frac{1}{9}, \frac{1}{7}\right) \\
\frac{1}{\mathrm{E}}:\left(\frac{1}{7}, \frac{1}{5}, \frac{1}{3}\right)\end{array}$ & $\begin{array}{l}\frac{1}{\mathrm{~L}}:\left(\frac{1}{4}, \frac{1}{3}, 1\right) \\
\frac{1}{\mathrm{E}}:\left(\frac{1}{7}, \frac{1}{5}, \frac{1}{3}\right) \\
\frac{1}{\mathrm{~L}}:\left(\frac{1}{4}, \frac{1}{3}, 1\right)\end{array}$ & $\begin{array}{c}\frac{1}{\mathrm{H}}:\left(\frac{1}{9}, \frac{1}{7}, \frac{1}{6}\right) \\
\frac{1}{\mathrm{VH}}:\left(\frac{1}{10}, \frac{1}{9}, \frac{1}{7}\right) \\
\frac{1}{\mathrm{E}}:\left(\frac{1}{7}, \frac{1}{5}, \frac{1}{3}\right)\end{array}$ & $(1,1,1)$ & $\begin{array}{l}\text { H: }(6,7,9) \\
\text { L: }(1,3,4) \\
\text { E: }(3,5,7)\end{array}$ \\
\hline $\begin{array}{l}\text { C6 : } \\
\text { Validation }\end{array}$ & $\begin{array}{l}\frac{1}{\mathrm{~L}}:\left(\frac{1}{4}, \frac{1}{3}, 1\right) \\
\frac{1}{\mathrm{~L}}:\left(\frac{1}{4}, \frac{1}{3}, 1\right) \\
\frac{1}{\mathrm{~L}}:\left(\frac{1}{4}, \frac{1}{3}, 1\right)\end{array}$ & $\begin{array}{l}\frac{1}{\mathrm{~L}}:\left(\frac{1}{4}, \frac{1}{3}, 1\right) \\
\frac{1}{\mathrm{~L}}:\left(\frac{1}{4}, \frac{1}{3}, 1\right) \\
\frac{1}{\mathrm{E}}:\left(\frac{1}{7}, \frac{1}{5}, \frac{1}{3}\right)\end{array}$ & $\begin{array}{l}\frac{1}{\mathrm{~L}}:\left(\frac{1}{4}, \frac{1}{3}, 1\right) \\
\frac{1}{\mathrm{~L}}:\left(\frac{1}{4}, \frac{1}{3}, 1\right) \\
\frac{1}{\mathrm{~L}}:\left(\frac{1}{4}, \frac{1}{3}, 1\right)\end{array}$ & $\begin{array}{l}\frac{1}{\mathrm{~L}}:\left(\frac{1}{4}, \frac{1}{3}, 1\right) \\
\frac{1}{\mathrm{~L}}:\left(\frac{1}{4}, \frac{1}{3}, 1\right) \\
\frac{1}{\mathrm{E}}:\left(\frac{1}{7}, \frac{1}{5}, \frac{1}{3}\right)\end{array}$ & $\begin{array}{l}\frac{1}{\mathrm{H}}:\left(\frac{1}{9}, \frac{1}{7}, \frac{1}{6}\right) \\
\frac{1}{\mathrm{~L}}:\left(\frac{1}{4}, \frac{1}{3}, 1\right) \\
\frac{1}{\mathrm{E}}:\left(\frac{1}{7}, \frac{1}{5}, \frac{1}{3}\right)\end{array}$ & $(1,1,1)$ \\
\hline
\end{tabular}

TABLE IV. ESTIMATED NORMALIZED FuZZY WEIGHTS OF DECISION CRITERIA

\begin{tabular}{|c|c|c|c|}
\hline \multirow{2}{*}{ Criteria } & \multicolumn{3}{|c|}{ Estimated normalized weight } \\
\cline { 2 - 4 } & $\boldsymbol{\alpha}_{\boldsymbol{i l}}$ & $\boldsymbol{\alpha}_{\boldsymbol{i} \boldsymbol{m}}$ & $\boldsymbol{\alpha}_{\boldsymbol{i} \boldsymbol{u}}$ \\
\hline C1 & 0.0225 & 0.0275 & 0.0319 \\
\hline $\mathbf{C 2}$ & 0.0187 & 0.0308 & 0.0424 \\
\hline $\mathbf{C 3}$ & 0.1266 & 0.1310 & 0.1322 \\
\hline $\mathbf{C 4}$ & 0.1388 & 0.1468 & 0.1511 \\
\hline C5 & 0.4256 & 0.4483 & 0.4599 \\
\hline C6 & 0.1259 & 0.2252 & 0.3212 \\
\hline
\end{tabular}

The table $\mathrm{V}$ below shows an example of the fuzzy pairwise comparisons matrix of the modeling methods filled by the committee. The comparisons are done based on the Criteria 1.

The computation of $\widetilde{\beta_{1 j}}=\left(\beta_{\mathrm{ijl}}, \beta_{\mathrm{ijm}}, \beta_{\mathrm{iju}}\right)$, corresponding to the fuzzy weights of methods $\mathrm{j}(\mathrm{j}=1, \ldots, n)$ that are calculated under each criteria $c_{i}(i=1, \ldots, m)$ separately, is made in the same way by using the same formulas (2-8).

The tables VI to XI present the estimated fuzzy weights of modeling methods under criteria 1 to 6 (See Figure 5). 
TABLE V. FuZZY PAIRWISE COMPARISONS OF MODELING METHODS UNDER CRITERIA 1

\begin{tabular}{|c|c|c|c|c|c|c|}
\hline & M1: GRAI/GIM & M2: ARIS & M3: UML & M4: Petri Networks & M5: BPMN & M6: SCOR \\
\hline $\begin{array}{l}\text { M1: GRAI/ } \\
\text { GIM }\end{array}$ & $(1,1,1)$ & $\begin{array}{l}\mathrm{L}:(1,3,4) \\
\mathrm{E}:(3,5,7) \\
\mathrm{H}:(6,7,9)\end{array}$ & $\begin{array}{l}\text { E: }(3,5,7) \\
\text { L: }(1,3,4) \\
\text { L: }(1,3,4)\end{array}$ & $\begin{array}{l}\text { L: }(1,3,4) \\
\text { L: }(1,3,4) \\
\text { L: }(1,3,4)\end{array}$ & $\begin{array}{l}\text { L: }(1,3,4) \\
\text { L: }(1,3,4) \\
\text { L: }(1,3,4)\end{array}$ & $\begin{array}{l}\text { E: }(3,5,7) \\
\text { H:(6,7,9) } \\
\text { L: }(1,3,4)\end{array}$ \\
\hline M2: ARIS & $\begin{array}{l}\frac{1}{\mathrm{~L}}:\left(\frac{1}{4}, \frac{1}{3}, 1\right) \\
\frac{1}{\mathrm{E}}:\left(\frac{1}{7}, \frac{1}{5}, \frac{1}{3}\right) \\
\frac{1}{\mathrm{H}}:\left(\frac{1}{9}, \frac{1}{7}, \frac{1}{6}\right)\end{array}$ & $(1,1,1)$ & $\begin{array}{l}\text { E: }(3,5,7) \\
\text { E: }(3,5,7) \\
\text { L: }(1,3,4)\end{array}$ & $\begin{array}{l}\text { L: }(1,3,4) \\
\text { L: }(1,3,4) \\
\text { E: }(3,5,7)\end{array}$ & $\begin{array}{l}\text { L: }(1,3,4) \\
\text { L: }(1,3,4) \\
\text { L: }(1,3,4)\end{array}$ & $\begin{array}{l}\mathrm{H}:(6,7,9) \\
\mathrm{H}:(6,7,9) \\
\mathrm{E}:(3,5,7)\end{array}$ \\
\hline M3: UML & $\begin{array}{l}\frac{1}{\mathrm{E}}:\left(\frac{1}{7}, \frac{1}{5}, \frac{1}{3}\right) \\
\frac{1}{\mathrm{~L}}:\left(\frac{1}{4}, \frac{1}{3}, 1\right) \\
\frac{1}{\mathrm{~L}}:\left(\frac{1}{4}, \frac{1}{3}, 1\right)\end{array}$ & $\begin{array}{l}\frac{1}{\mathrm{E}}:\left(\frac{1}{7}, \frac{1}{5}, \frac{1}{3}\right) \\
\frac{1}{\mathrm{E}}:\left(\frac{1}{7}, \frac{1}{5}, \frac{1}{3}\right) \\
\frac{1}{\mathrm{~L}}:\left(\frac{1}{4}, \frac{1}{3}, 1\right)\end{array}$ & $(1,1,1)$ & $\begin{array}{l}\text { E: }(3,5,7) \\
\text { E: }(3,5,7) \\
\text { L: }(1,3,4)\end{array}$ & $\begin{array}{l}\text { L: }(1,3,4) \\
\text { L: }(1,3,4) \\
\text { L: }(1,3,4)\end{array}$ & $\begin{array}{l}\mathrm{H}:(6,7,9) \\
\mathrm{H}:(6,7,9) \\
\mathrm{E}:(3,5,7)\end{array}$ \\
\hline $\begin{array}{l}\text { M4: Petri } \\
\text { Networks }\end{array}$ & $\begin{array}{l}\frac{1}{\mathrm{~L}}:\left(\frac{1}{4}, \frac{1}{3}, 1\right) \\
\frac{1}{\mathrm{~L}}:\left(\frac{1}{4}, \frac{1}{3}, 1\right) \\
\frac{1}{\mathrm{~L}}:\left(\frac{1}{4}, \frac{1}{3}, 1\right)\end{array}$ & $\begin{array}{l}\frac{1}{\mathrm{~L}}:\left(\frac{1}{4}, \frac{1}{3}, 1\right) \\
\frac{1}{\mathrm{~L}}:\left(\frac{1}{4}, \frac{1}{3}, 1\right) \\
\frac{1}{\mathrm{E}}:\left(\frac{1}{7}, \frac{1}{5}, \frac{1}{3}\right)\end{array}$ & $\begin{array}{l}\frac{1}{\mathrm{E}}:\left(\frac{1}{7}, \frac{1}{5}, \frac{1}{3}\right) \\
\frac{1}{\mathrm{E}}:\left(\frac{1}{7}, \frac{1}{5}, \frac{1}{3}\right) \\
\frac{1}{\mathrm{~L}}:\left(\frac{1}{4}, \frac{1}{3}, 1\right)\end{array}$ & $(1,1,1)$ & $\begin{array}{l}\text { L: }(1,3,4) \\
\text { E: }(3,5,7) \\
\text { E: }(3,5,7)\end{array}$ & $\begin{array}{l}\text { H:(6,7,9) } \\
\text { VH:(7,9,10) } \\
\text { E: }(3,5,7)\end{array}$ \\
\hline M5: BPMN & $\begin{array}{l}\frac{1}{\mathrm{~L}}:\left(\frac{1}{4}, \frac{1}{3}, 1\right) \\
\frac{1}{\mathrm{~L}}:\left(\frac{1}{4}, \frac{1}{3}, 1\right) \\
\frac{1}{\mathrm{~L}}:\left(\frac{1}{4}, \frac{1}{3}, 1\right)\end{array}$ & $\begin{array}{l}\frac{1}{\mathrm{~L}}:\left(\frac{1}{4}, \frac{1}{3}, 1\right) \\
\frac{1}{\mathrm{~L}}:\left(\frac{1}{4}, \frac{1}{3}, 1\right) \\
\frac{1}{\mathrm{~L}}:\left(\frac{1}{4}, \frac{1}{3}, 1\right)\end{array}$ & $\begin{array}{l}\frac{1}{\mathrm{~L}}:\left(\frac{1}{4}, \frac{1}{3}, 1\right) \\
\frac{1}{\mathrm{~L}}:\left(\frac{1}{4}, \frac{1}{3}, 1\right) \\
\frac{1}{\mathrm{~L}}:\left(\frac{1}{4}, \frac{1}{3}, 1\right)\end{array}$ & $\begin{array}{l}\frac{1}{\mathrm{~L}}:\left(\frac{1}{4}, \frac{1}{3}, 1\right) \\
\frac{1}{\mathrm{E}}:\left(\frac{1}{7}, \frac{1}{5}, \frac{1}{3}\right) \\
\frac{1}{\mathrm{E}}:\left(\frac{1}{7}, \frac{1}{5}, \frac{1}{3}\right)\end{array}$ & $(1,1,1)$ & $\begin{array}{l}\text { H: }(6,7,9) \\
\text { VH: }(7,9,10) \\
\text { H:(6,7,9) }\end{array}$ \\
\hline M6: SCOR & $\begin{array}{l}\frac{1}{\mathrm{E}}:\left(\frac{1}{7}, \frac{1}{5}, \frac{1}{3}\right) \\
\frac{1}{\mathrm{H}}:\left(\frac{1}{9}, \frac{1}{7}, \frac{1}{6}\right) \\
\frac{1}{\mathrm{~L}}:\left(\frac{1}{4}, \frac{1}{3}, 1\right)\end{array}$ & $\begin{array}{l}\frac{1}{\mathrm{H}}:\left(\frac{1}{9}, \frac{1}{7}, \frac{1}{6}\right) \\
\frac{1}{\mathrm{H}}:\left(\frac{1}{9}, \frac{1}{7}, \frac{1}{6}\right) \\
\frac{1}{\mathrm{E}}:\left(\frac{1}{7}, \frac{1}{5}, \frac{1}{3}\right)\end{array}$ & $\begin{array}{l}\frac{1}{\mathrm{H}}:\left(\frac{1}{9}, \frac{1}{7}, \frac{1}{6}\right) \\
\frac{1}{\mathrm{H}}:\left(\frac{1}{9}, \frac{1}{7}, \frac{1}{6}\right) \\
\frac{1}{\mathrm{E}}:\left(\frac{1}{7}, \frac{1}{5}, \frac{1}{3}\right)\end{array}$ & $\begin{array}{l}\frac{1}{\mathrm{H}}:\left(\frac{1}{9}, \frac{1}{7}, \frac{1}{6}\right) \\
\frac{1}{\mathrm{VH}}:\left(\frac{1}{10}, \frac{1}{9}, \frac{1}{7}\right) \\
\frac{1}{\mathrm{E}}:\left(\frac{1}{7}, \frac{1}{5}, \frac{1}{3}\right)\end{array}$ & $\begin{array}{l}\frac{1}{\mathrm{H}}:\left(\frac{1}{9}, \frac{1}{7}, \frac{1}{6}\right) \\
\frac{1}{\mathrm{VH}}:\left(\frac{1}{10}, \frac{1}{9}, \frac{1}{7}\right) \\
\frac{1}{\mathrm{H}}:\left(\frac{1}{9}, \frac{1}{7}, \frac{1}{6}\right)\end{array}$ & $(1,1,1)$ \\
\hline
\end{tabular}

TABLE VI. Estimated NORMALIZED FuZZY WEIGHTS OF MODELING METHODS UNDER CRITERIA 1

\begin{tabular}{|l|l|l|l|}
\hline \multirow{2}{*}{ Criteria } & \multicolumn{3}{|c|}{ Estimated normalized weight } \\
\cline { 2 - 4 } & \multicolumn{1}{|c|}{$\boldsymbol{\alpha}_{\boldsymbol{i l}}$} & \multicolumn{1}{c|}{$\boldsymbol{\alpha}_{\boldsymbol{i m}}$} & $\boldsymbol{\alpha}_{\boldsymbol{i} \boldsymbol{u}}$ \\
\hline M1: GRAI/GIM & 0.0146 & 0.0533 & 0.0917 \\
\hline M2: ARIS & 0.0508 & 0.0850 & 0.1179 \\
\hline M3: UML & 0.1220 & 0.1349 & 0.1446 \\
\hline M4: Petri Networks & 0.3989 & 0.5414 & 0.6736 \\
\hline M5: BPMN & 0.1535 & 0.5527 & 0.7480 \\
\hline M6: SCOR & 0.0062 & 0.0354 & 0.0645 \\
\hline
\end{tabular}

TABLE VII. ESTIMATED NORMALIZED FuZZY WEIGHTS OF MODELING METHODS UNDER CRITERIA 2

\begin{tabular}{|l|l|l|l|}
\hline \multirow{2}{*}{ Criteria } & \multicolumn{3}{|c|}{ Estimated normalized weight } \\
\cline { 2 - 4 } & \multicolumn{1}{|c|}{$\boldsymbol{\alpha}_{\boldsymbol{i l}}$} & $\boldsymbol{\alpha}_{\boldsymbol{i m}}$ & \multicolumn{1}{c|}{$\boldsymbol{\alpha}_{\boldsymbol{i u}}$} \\
\hline M1: GRAI/GIM & 0.0169 & 0.0504 & 0.0835 \\
\hline M2: ARIS & 0.0566 & 0.0830 & 0.1080 \\
\hline M3: UML & 0.1325 & 0.1345 & 0.1330 \\
\hline M4: Petri Networks & 0.4186 & 0.5449 & 0.6603 \\
\hline M5: BPMN & 0.1414 & 0.5650 & 0.7450 \\
\hline M6: SCOR & 0.0055 & 0.0361 & 0.0666 \\
\hline
\end{tabular}

TABLE VIII. ESTIMATED NORMALIZED FuZZY WEIGHTS OF MODELING METHODS UNDER CRITERIA 3

\begin{tabular}{|l|l|l|l|}
\hline \multirow{2}{*}{ Criteria } & \multicolumn{3}{|c|}{ Estimated normalized weight } \\
\cline { 2 - 4 } & \multicolumn{1}{|c|}{$\boldsymbol{\alpha}_{\text {il }}$} & \multicolumn{1}{c|}{$\boldsymbol{\alpha}_{\text {im }}$} & $\boldsymbol{\alpha}_{\text {iu }}$ \\
\hline M1: GRAI/GIM & 0.0080 & 0.0422 & 0.0761 \\
\hline M2: ARIS & 0.0433 & 0.0691 & 0.0938 \\
\hline M3: UML & 0.1337 & 0.1281 & 0.1190 \\
\hline M4: Petri Networks & 0.5414 & 0.5823 & 0.6491 \\
\hline M5: BPMN & 0.1193 & 0.6056 & 0.6887 \\
\hline M6: SCOR & 0.0039 & 0.0271 & 0.0502 \\
\hline
\end{tabular}

TABLE IX. ESTIMATED NORMALIZED FUZZY WEIGHTS OF MODELING METHODS UNDER CRITERIA 4

\begin{tabular}{|l|l|l|l|}
\hline \multirow{2}{*}{ Criteria } & \multicolumn{3}{|c|}{ Estimated normalized weight } \\
\cline { 2 - 4 } & \multicolumn{1}{|c|}{$\boldsymbol{\alpha}_{\text {il }}$} & \multicolumn{1}{|c|}{$\boldsymbol{\alpha}_{\text {im }}$} & $\boldsymbol{\alpha}_{\text {iu }}$ \\
\hline M1: GRAI/GIM & 0.0063 & 0.0482 & 0.0900 \\
\hline M2: ARIS & 0.0747 & 0.0850 & 0.0923 \\
\hline M3: UML & 0.0878 & 0.1060 & 0.1219 \\
\hline M4: Petri Networks & 0.5129 & 0.5921 & 0.6488 \\
\hline M5: BPMN & 0.1258 & 0.4265 & 0.7240 \\
\hline M6: SCOR & 0.0079 & 0.0290 & 0.0496 \\
\hline
\end{tabular}


TABLE X. Estimated NoRMALIZED FuZZY WeIGHTS OF MODELING METHODS UNDER CRITERIA 5

\begin{tabular}{|l|l|l|c|}
\hline \multirow{2}{*}{ Criteria } & \multicolumn{3}{|c|}{ Estimated normalized weight } \\
\cline { 2 - 4 } & \multicolumn{1}{|c|}{$\alpha_{\mathrm{il}}$} & \multicolumn{1}{c|}{$\alpha_{\mathrm{im}}$} & $\boldsymbol{\alpha}_{\mathrm{iu}}$ \\
\hline M1: GRAI/GIM & 0.0088 & 0.0388 & 0.0686 \\
\hline M2: ARIS & 0.0704 & 0.0865 & 0.1007 \\
\hline M3: UML & 0.1021 & 0.1078 & 0.1108 \\
\hline M4: Petri Networks & 0.1378 & 0.3658 & 0.5902 \\
\hline M5: BPMN & 0.1083 & 0.3829 & 0.6547 \\
\hline M6: SCOR & 0.0056 & 0.0271 & 0.0484 \\
\hline
\end{tabular}

TABLE XI. ESTIMATED NORMALIZED FuZZY WEIGHTS OF MODELING METHODS UNDER CRITERIA 6

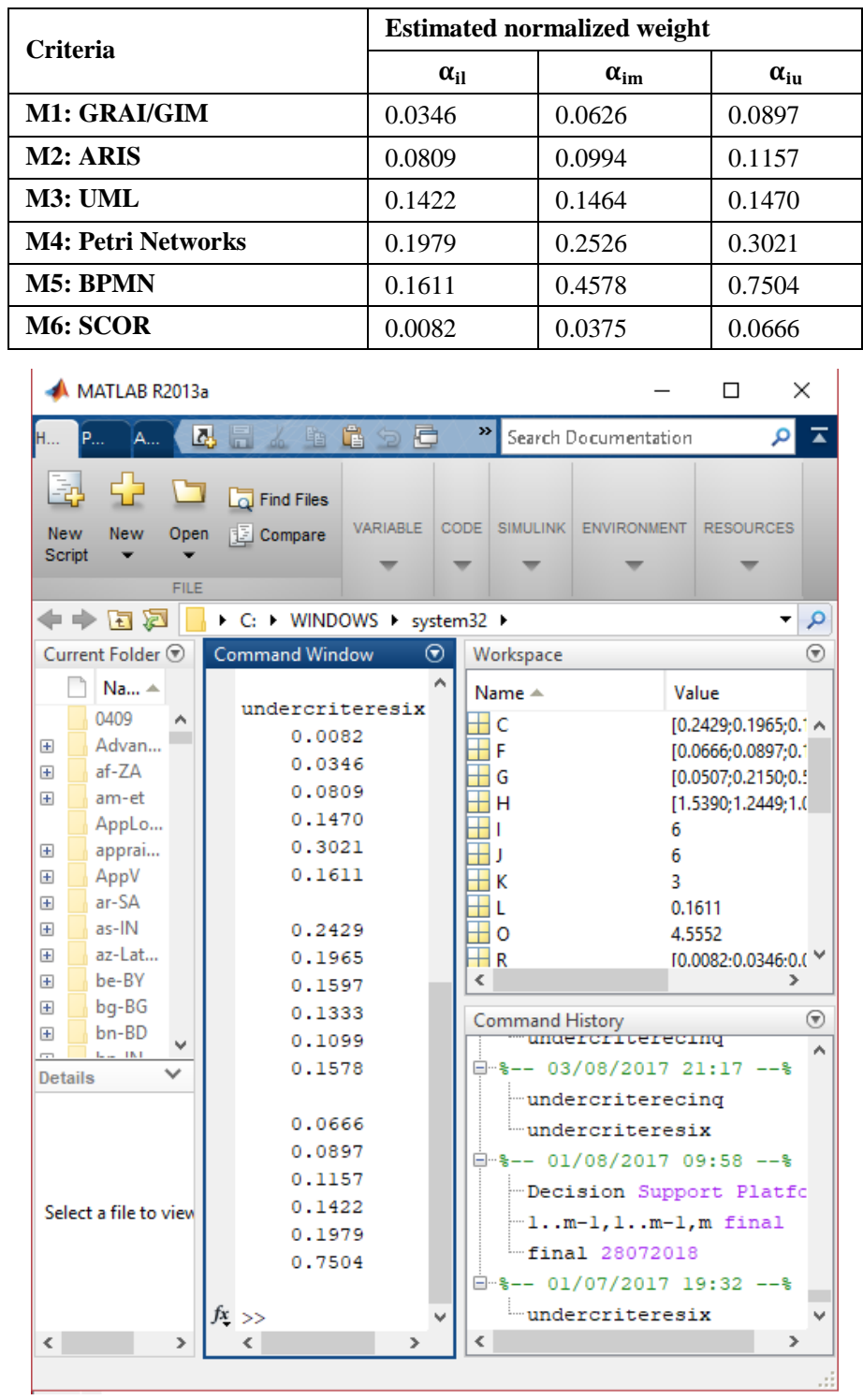

Fig. 5. Results of Weights Obtained by the Decision Support Platform.

Based to the obtained estimated fuzzy weights, the global weight is calculated for each method on the base of the formula $\mathrm{N}^{\circ} 1$.
TABLE XII. FuZZY WEIGHTS OF MODELING METHODS UNDER EACH CRITERIA

\begin{tabular}{|l|l|}
\hline Modeling method & Fazzy weighs \\
\hline M1 & $(0,01060,04710,0905)$ \\
\hline M2 & $(0,05820,08120,1082)$ \\
\hline M3 & $(0,09570,12560,1464)$ \\
\hline M4 & $(0,24010,49260,7000)$ \\
\hline M5 & $(0,10500,48370,8295)$ \\
\hline M6 & $(0,00520,03350,0843)$ \\
\hline
\end{tabular}

From the table above (Table XII) it is noticed that M5 (BPMN) and M4 (Petri Nets) have the best notations (see table XII). So, for this study case (the hospital supply chain), the modeling method adopted will be M5 (BPMN), M4 (Petri Networks) or a hybridization between them.

\section{CONCLUSION}

The present work consisted, at the first, on giving a global view about the hospital supply chain and its global structure organization as it is given by the literature. Secondly, a literature review about the modeling methods which are used in the hospital supply chain was presented. The objectives of the modeling approach and its relationship with the performance analysis approach was subsequently justified. Afterwards, the research methodology that is adopted in this work was given for designing our decision support platform. In fact, a classification study based on the cross sorting methods and the fuzzy pairwise comparisons has been developed as part of a computer platform. For that, six criteria were developed in our case and were request from three experts to fill the comparison matrices concerning criteria and modeling methods by considering the hospital supply chain context. This contribution will facilitate the selection of the best modeling methods for our case and the best alternative in a general context. After several iterations, it has been concluded that BPMN and Petri Networks methods had the best notations. In our future work, we plan to improve and automate the decision support platform and to opt for the selected methods or a hybridization of them for modeling the cold supply chain in the hospital.

\section{REFERENCES}

[1] Ouzayd, F., Saadi, J., Benhra, J., Proposed a simulation models in medicine drugs circuit with UML and Colored Petri Net: case Moroccan hospital system, International Review of modeling and simulation (IREMOS), Vol. 5. n. 1, pp. 489-496, 2012.

[2] M. Tamir, F. Ouzayd, R.Chiheb, "Literature Review and Classification of Performance Analysis Methods: Hospital Supply Chain", Proceedings of the International Conference on Industrial Engineering and Operations Management (IEOM), Rabat, Morocco, April 11-13, 2017.

[3] V. Andre, P. Fenies, « Modélisation et simulation des flux logistiques du Nouvel Hôpital d'Estaing », Logistique \& Management, vol. 15(1), 2007.

[4] A. Artiba, M. Briquet, J. Colin, A. Dontaine, D. Gourc, C. Pourcel, R. Stock, "Modélisation d'établissement de santé ». Actes de la 2ème conférence francophone en Gestion et Ingénierie de Systèmes Hospitaliers (GISEH), Mons, Belgique, 2004.

[5] P. Féniès, M. Gourgand, N. Tchernev, « Une contribution à la mesure de la performance dans la supply chain hospitalière : L'exemple du processus opératoire », Actes de la 2e conférence francophone en Gestion et Ingénierie de Systèmes Hospitaliers (GISEH), 9-11, Mons, Belgique, Septembre 2004. 
[6] J. Jlassi, « Amélioration de la performance par la modélisation des flux logistiques des patients dans un service d'urgence hospitalier », Doctoral Thesis, 2011.

[7] T. Hassan, «Logistique hospitalière : organisation de la chaine logistique pharmaceutique aval et optimisation des flux de consommables et des matériels à usage unique». Doctoral Thesis in Computer Science, INSA de Lyon, 2006.

[8] L. Boyer, M. Poirée, and E., Salin, Précis d'organisation et de gestion de la production, Les éditions d'organisation, Paris, 1982.

[9] G. Chow and TD. Heaver, Logistics in the Canadian, health care industry, Canadian Logistics Journal, Vol. 1, No. 1, December 1994.

[10] ASLOG - Commission logistique hospitalière, Résultats de l'enquête nationale, Hôpital Expo Conférence, Paris, http://www;genecodean.fr/download/nonprotege/d3_nos_manifestation/ d312n_hexpo/ASLOG.df, 21 mai 2002.

[11] K. Swinehart, T.W. Zimmerer, S. Oswald, Adapting a Strategic Management Model to Hospital Operating Strategies. Journal of Management Medicine 9 (2): 34-47, 1995.

[12] N. Sampieri-Teissier, Proposition d'une typologie des pratiques logistiques des hôpitaux publics français. Enseignements à partir d'une étude empirique. Logistique et Management 10 (1): 85- 95, 2002.

[13] Elhamdi, M., Modélisation et simulation de chaines de valeurs en entreprise - Une approche dynamique des systèmes et aide à la décision : SimulValor, Sciences de l'ingénieur [physics]. Ecole Centrale Paris, Français, 2005

[14] Villa, S., Prenestini, A., Giusepi, I., A framework to analy ze hospital wide patient flow logistics:Evidence from an Italian comparative study, Health Policy 115, 196-205, 2014.

[15] P. Bhattacharjee, Ray, P.K., Patient Flow Modelling and Performance Analysis of Healthcare Delivery Processes in Hospitals: A Review and Reflections, Computers \& Industrial Engineering, http://dx.doi.org/10.1016/j.cie.2014.04.016, 2014.

[16] A.M. Caunhye, Xiaofeng N., Pokharel S., Optimization models in emergency logistics: A literature review, SocioEconomic Planning Sciences, 46, 4e13, 2012.

[17] A.D. Marshall, Burgos-Liz, L., Maarten, J., IJzerman, Nathaniel, D., Osgood, William, V., Padula, Mitchell, K., Higashi, Peter, K., Wong, Kalyan, S., Pasupathy, William, Crown, Applying Dynamic Simulation Modeling Methods in Health Care Delivery Research: The SIMULATE Checklist :Report of the ISPOR Simulation Modeling Emerging Good Practices Task Force, International Society for Pharmacoeconomics and Outcomes Research (ISPOR), 2015.

[18] Y. Jacquemin, Optimisation de la trajectoire du patient dans les centres de radiothérapie ou d'hadronthérapie, Doctoral Thesis, École doctorale Science, Ingénierie et Santé de Saint-Etienne, 2011.

[19] Khlie K., A.Abouabdellah, Modeling and simulation of the patients pathway with ARENA: Case of the Mother-Child Hospital at MARRAKECH, Xth International Conference on Integrated Design and Production, CPI 2015, December 2-4, 2015, Tangier - Morocco.

[20] G.FONTAN, D.DUROU, C.MERCÉ, "Analyse et modélisation du parcours du patient, Logistique et management", Logistique \& Management Journal, Volume 12, 2004 - Issue sup1, 2015.

[21] Y. Shen and Lin Hui L., "Improving the wait time to consultation at the emergency department”, BMJ Open Qual Volume 7(1); 2018.

[22] S. Jebbor, A. El Afia, R. Chiheb (2018) "Reducing Crowding in Hospital Inpatient Unit Using Queuing Theory". In: Ezziyyani M., Bahaj M., Khoukhi F. (eds) Advanced Information Technology, Services and Systems. AIT2S 2017. Lecture Notes in Networks and Systems, vol 25. Springer, Cham.

[23] B. Idriss, J. Saadi, A. Bellabdaoui, « Modélisation et Simulation dans les centres de transfusion sanguine: Cas du CRTS de Casablanca», Conference: GISEH, July, 2016.
[24] P. Staccini, M. Joubert, J.F. Quaranta, M. Fieschi (2003). Mapping care processes within a hospital: A web-based proposal merging enterprise modelling and.ISO normative principles. Studies in Health Technology and Informatics, vol 95, pp.200-205, 2003.

[25] A.Vincent, "Modélisation, analyse et pilotage de flux en milieu hospitalier à l'aide d'UML et des réseaux de Petri, Engineering Sciences », Doctoral Thesis, Ecole Nationale Supérieure des Mines de Saint-Etienne, 2008.

[26] M.A. El oualidi, J. Saadi, L. El hiki, A. Artiba, A. Bellabdaoui, «Modélisation et simulation du flux des patients au service des urgences. Cas de l'hôpital Ibn Rochd à Casablanca (Maroc)", Francophone Conference of Management and Engineering of Hospital Systems, 2010.

[27] H. Benabdejlil, «Modélisation des processus de soins: vers une implantation de nouveaux services à valeur ajoutée Hajar Benabdejlil To cite this version », Doctoral Thesis, UNIVERSITÉ DE BORDEAUX, France, 2016.

[28] Q. Laval, A. Ferrarini, S. Rodier, S. Norre, "A Modeling Approach of an Hospital Logistics System: Application to the AP-HM Logistics Platform", Journal Logistique \& Management, vol 22(4), pp. 5-22, 2014 (7ème Conférence GISEH 2014. Gestion et Ingénierie des Systèmes Hospitaliers).

[29] F. Ouzayd, «Apport de la modélisation et simulation du flux médicamenteux direct et inverse au sein d'une pharmacie hospitalière : Cas de l'hôpital Ibn Tofail », Doctoral Thesis, Université Hassan II Casablanca, Ecole Nationale Supérieure d'Electricité \& de Mécanique, 2014.

[30] M.Chabrol, P. Féniès, M. Gourgand, N.Tchernev, « Un environnement de modélisation pour le système d'information de la Supply Chain. Application au Nouvel Hôpital Estaing », Ingénierie des systèmes d'information, vol. 11(1), pp.137-162, 2006.

[31] R. Iannone, A. Lambiase, S. Miranda, S. Riemma, D. Sarno, "Modelling hospital materials management processes", International Journal of Engineering Business Management, vol 2(1), pp.1-12, 2013.

[32] H. Mezouar, A. El afia, R. Chiheb, F. Ouzayd, "Proposal of a modeling approach and a set of KPI to the drug supply chain within the hospital", Proceeding in Logistics Operations Management (GOL), 3rd International Conference, IEEE, 2016.

[33] W. Chanpuypetch, D. Kritchanchai, «A Process Reference Model for Hospital Supply Chain of Pharmaceutical Products ». Industrial Engineerin \& Management Systems, vol 17, No 1, pp.43-61, March 2018.

[34] Matthieu, L.M., Méthodes de diagnostic et d'évaluation de performance pour la gestion de chaînes logistiques : application à la coopération maison-mère - filiales internationales dans un groupe pharmaceutique et cosmétique, Doctoral Thesis, L'institut Nationale polytechnique de Toulouze, 2004.

[35] CEN ENV 40003, Enterprise Integration-Framework for Enterprise Modelling, European Committe for Standardization, 2001.

[36] F. Limayem (2006). Modèles de pondération par les méthodes de tri croisé pour l'aide à la décision collaborative en projet, Doctoral Thesis, France, 2006.

[37] Idri, A., Impacts des techniques de construction des ensembles flous sur la precision d'un modèle d'estimation des couts de logiciels par analogie floue, SETIT, 2007.

[38] P.J.M Van Laarhoven, W. Pedrycz, “A fuzzy extension of Saaty's priority theory”. Fuzzy Sets and Systems, vol. 11, pp.229-241, 1983.

[39] C.G.E. Boender, J.G. de Graan and F.A. Lootsma, "Multi-criteria decision analysis with fuzzy pairwise comparisons", Fuzzy Sets and Systems, vol 29, 133-143, 1989

[40] O. Gogus, T. « O. Boucher, «A consistency test for rational weights in multi-criterion decision analysis with fuzzy pairwise comparisons». Fuzzy Sets and Systems, vol 86(2), pp.129-138, 1997 